Nordic Concrete Research - Publ. No. NCR 62 - ISSUE 1 / 2020 - Article 4, pp. 63-85

\begin{tabular}{|c|c|}
\hline$\$$ sciendo & 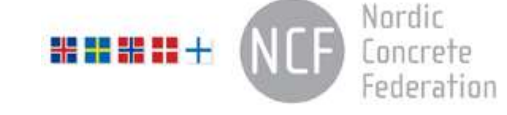 \\
\hline $\begin{array}{l}\text { C) Articleauthors.This is an open } \\
\text { accessarticledistributedunderthe Creative Commons } \\
\text { Attribution-NonCommercial- } \\
\text { NoDerivslicens.(http://creaticecommons.org/licenses/by.nc- } \\
\text { nd/3.0/). }\end{array}$ & $\begin{array}{l}\text { ISSN online } 2545-2819 \\
\text { ISSN print } \quad 0800-6377\end{array}$ \\
\hline DOI: $10.2478 /$ ncr-2020-0006 & $\begin{array}{r}\text { Received: March 31, } 2020 \\
\text { Revision received: May 6, } 2020 \\
\text { Accepted: May 7, } 2020\end{array}$ \\
\hline
\end{tabular}

\title{
Encapsulation Techniques and Test Methods of Evaluating the Bacteria- Based Self-Healing Efficiency of Concrete: A Literature Review
}

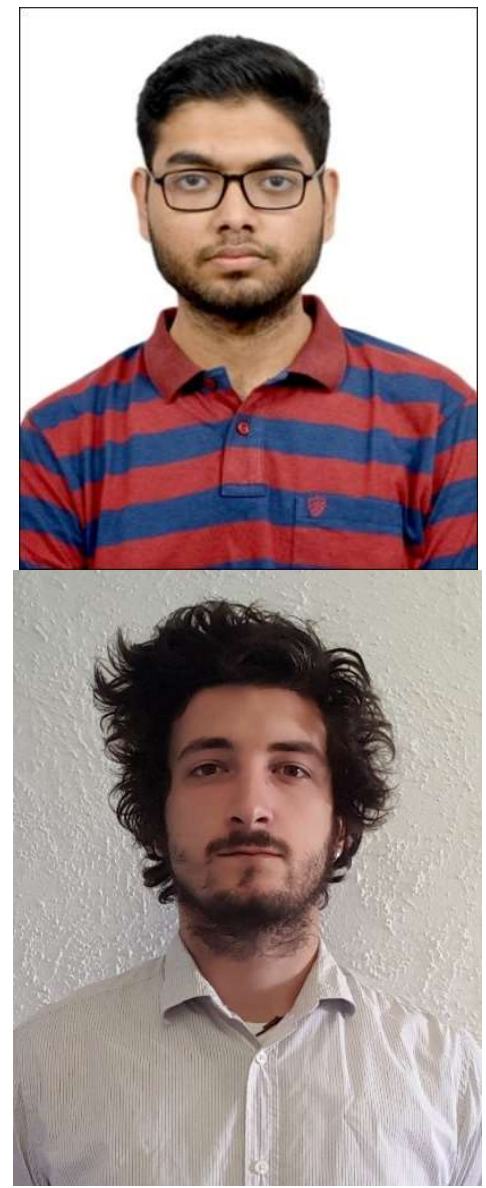

Rahul Roy

MSc. candidate

KTH Royal Institute of Technology

Division of Concrete Structures

Brinellvägen 23, 10044 Stockholm

rahulr@kth.se

Emanuele Rossi

$\mathrm{PhD}$ candidate

Technical University of Delft

Department of Materials \& Environment, Faculty of Civil

Engineering \& Geosciences

Stevinweg 1, 2628 CN Delft, The Netherlands

e.rossi@tudelft.nl 

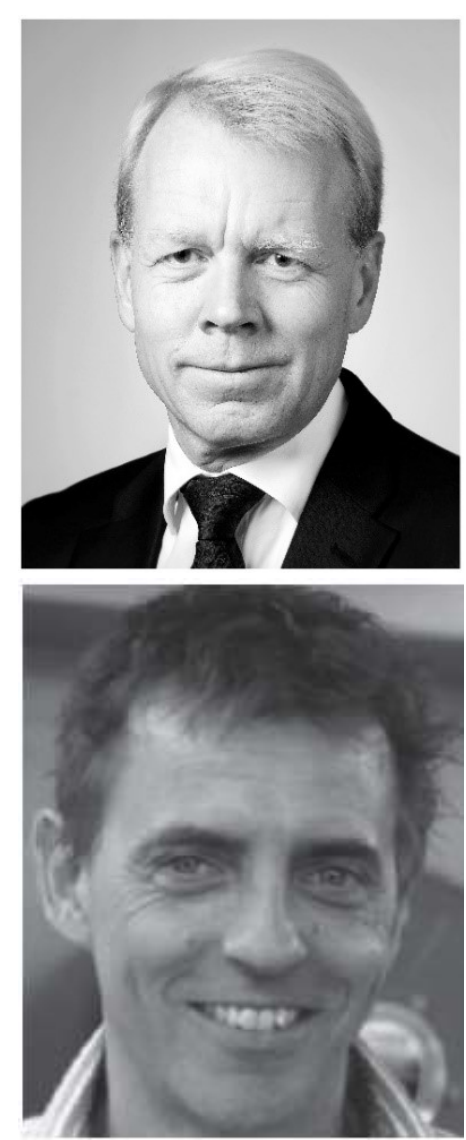

Johan Silfwerbrand

Professor

KTH Royal Institute of Technology

Division of Concrete Structures

Brinellvägen 23, 10044 Stockholm

jsilfwer@kth.se

\author{
Henk Jonkers \\ Professor \\ Technical University of Delft \\ Department of Materials \& Environment, Faculty of Civil \\ Engineering \& Geosciences \\ Stevinweg 1,2628 CN Delft, The Netherlands \\ h.m.jonkers@tudelft.nl
}

\begin{abstract}
Crack formation in concrete structures due to various load and non-load factors leading to degradation of service life is very common. Repair and maintenance operations are, therefore, necessary to prevent cracks propagating and reducing the service life of the structures. Accessibility to affected areas can, however, be difficult as the reconstruction and maintenance of concrete buildings are expensive in labour and capital. Autonomous healing by encapsulated bacteria-based self-healing agents is a possible solution. During this process, the bacteria are released from a broken capsule or triggered by water and oxygen access. However, its performance and reliability depend on continuous water supply, protection against the harsh environment, and densification of the cementitious matrix for the bacteria to act. There are vast methods of encapsulating bacteria and the most common carriers used are: encapsulation in polymeric materials, lightweight aggregates, cementitious materials, special minerals, nanomaterials, and waste-derived biomass. Self-healing efficiency of these encapsulated technologies can be assessed through many experimental methodologies according to the literature. These experimental evaluations are performed in terms of quantification of crackhealing, recovery of durability and mechanical properties (macro-level test) and characterization of precipitated crystals by healing agent (micro-level test). Until now, quantification of crack-healing by light microscopy revealed maximum crack width of $1.80 \mathrm{~mm}$ healed. All research methods available for assesing self-healing efficiency of bacteria-based healing agents are worth reviewing in order to include a coherent, if not standardized framework testing system and a comparative evaluation for a novel incorporated bacteria-based healing agent.
\end{abstract}

Key words: Calcium carbonate precipitation, Bacteria, Self-healing, Autonomous healing, Encapsulation, Experimental evaluations 
1.

INTRODUCTION

1.1

\section{Self-healing concrete}

The application of self-healing materials is rising in the field of civil engineering. The aim of self-healing in the area of concrete materials is to improve its functional properties and its service-life by recovering strength, porosity and water-tightness of the concrete. Self-healing in the field of concrete mainly implies the repair of cracks in concrete caused by its brittle nature. The process of self-healing mainly occurs through two major mechanisms: autogenous and autonomous healing, see Figure 1a [1]. One of the most commonly debated self-healing mechanisms is the inclusion of bacteria in concrete. The key aim of using bacteria in concrete materials is to focus on improving crack healing through autonomous healing in addition to autogenous concrete healing. This aims at integrating a better self-healing strategy known as "improved autogenous self-healing", as shown in Figurelb [2].

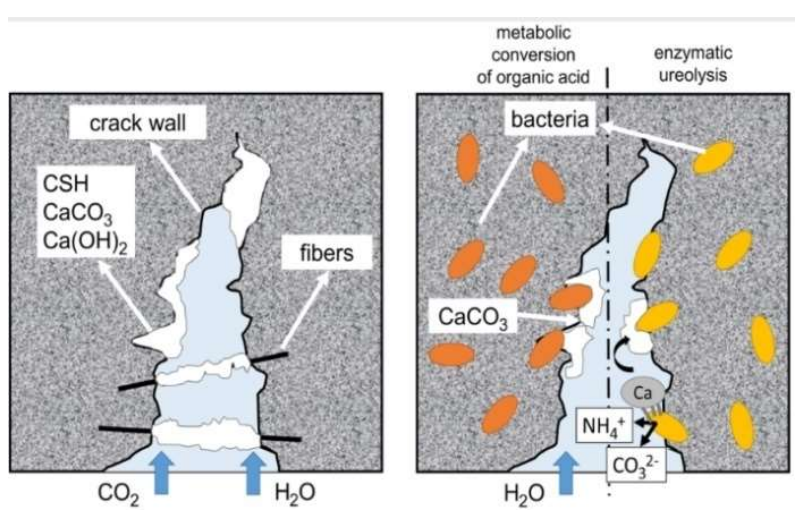

(a)

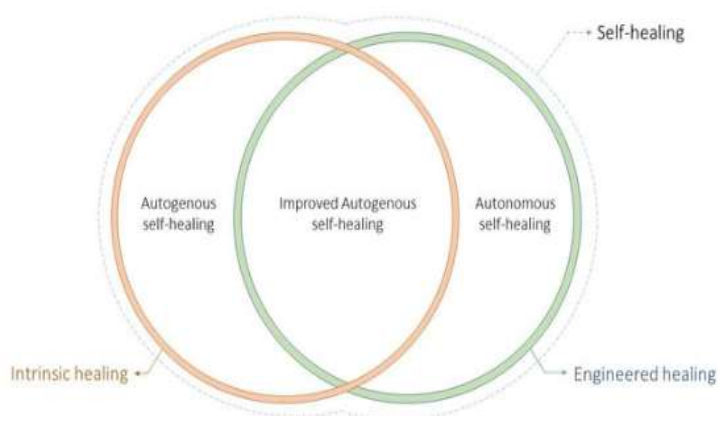

(b)

Figure 1 - (a) Left image corresponds to autogenous healing due to carbonation $\left(\mathrm{CaCO}_{3}\right)$ and continuous hydration (CSH, $\left.\mathrm{Ca}(\mathrm{OH})_{2}\right)$, right image corresponds to autonomous healing by bacteria metabolic conversion (left-metabolic conversion of organic acid; right-enzymatic Ureolysis) [1]. (b) Improved autogenous self-healing [2].

Autogenous self-healing in concrete involves crystal precipitation (i.e. calcium carbonate due to carbonation and calcium hydroxide and CSH due to continuous hydration of cement particles) that may restore cracks up to a specific width. This healing approach is prominent in the fresh state of the concrete. The mechanisms of self-healing can usually be classified into three major groups: physical, chemical, and mechanical. The physical effects include the swelling of the cement matrix at the opening of the crack as the hydrated cement matrix retains water. The chemical factors can be traced to two major processes: constant hydration of the portland cement and calcium carbonate formation due to carbonation of the concrete matrix. The mechanical causes of the autogenous self-healing are to fill cracks with small particles emerging from the fractured surface of concrete or being transported by a fluid to the crack [1].

In comparison, autonomous concrete healing encourages the use of external components like bacteria and microcapsules filled with healing agents to increase the material's self-healing capacity [3-17]. The mechanism of self-healing in these environments consists of calcium carbonate formation, whether by the bacterial metabolic conversion of an organic acid or the enzyme ureolysis. Bacteria-based self-healing concrete attracted significant attention in the 
recent years due to very promising results obtained from small scale laboratory studies; see Figure 2.

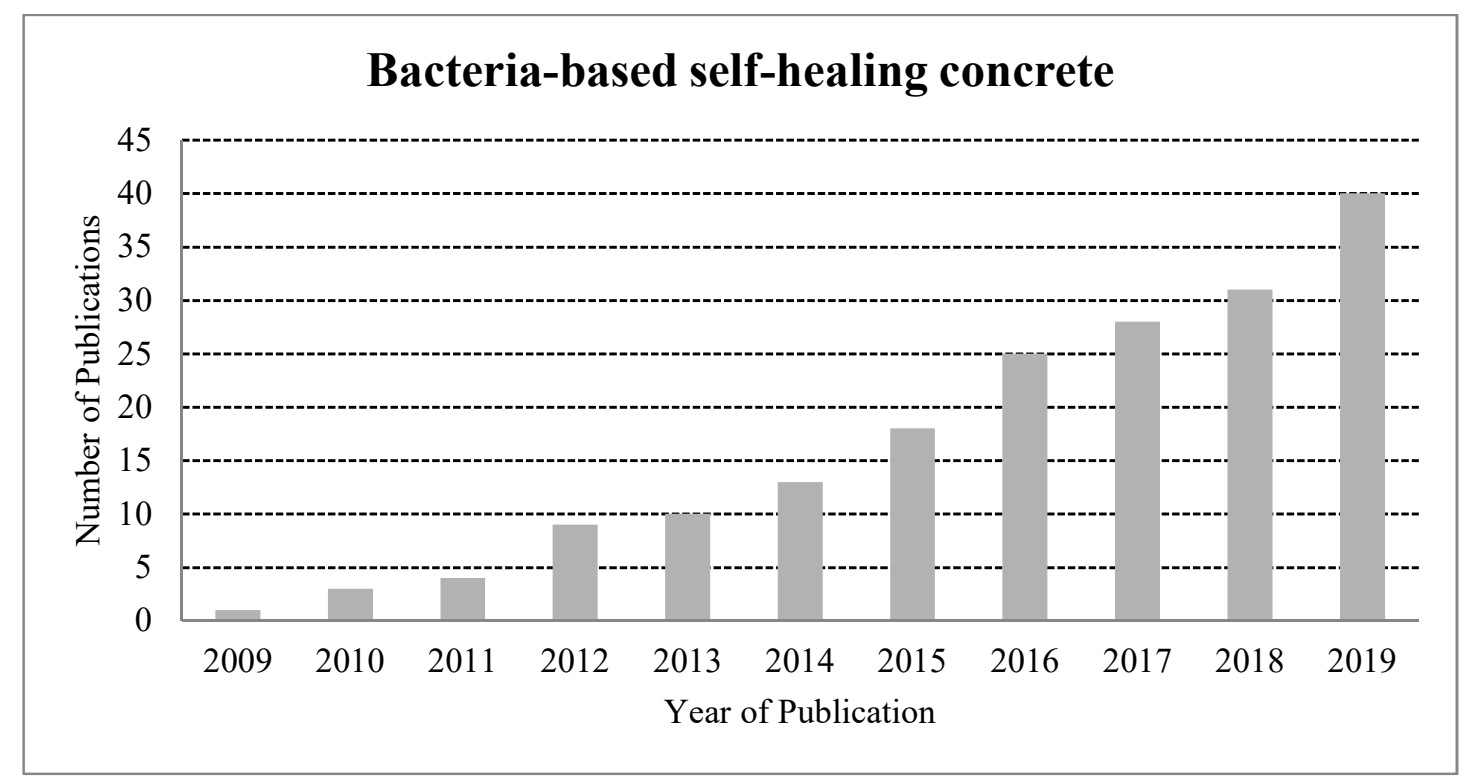

Figure 2 -Number of publications in the field of bacteria-based self-healing concrete.

\subsection{Calcium carbonate precipitation by bacterial metabolic pathways}

Calcareous deposition and other concrete mineral types can be beneficial and durable because they are compliant with concrete materials. Crack-filling of concrete-compatible minerals, for example, improves the waterproofing of concrete while protecting the embedded reinforcement of steel against adverse compounds, such as chlorides or other corrosion-stimulating ions, which move quickly through micro cracks. Hence, the recovery of functional concrete properties such as water-tightness and mechanical strength is one of the primary objectives of using calcareous deposition to stimulate bacteria. Calcium carbonate precipitation is typically affected by the calcium ion concentration, $\mathrm{pH}$ solution concentration, the dissolved inorganic carbon concentration, and the existence of nucleation sites in the natural environment [18]. While the first three conditions concern the concrete matrix, the fourth condition is dependent on the bacterial cell itself. Bacterial precipitation may be accomplished by different assimilating and dissimilating pathways of the heterotrophic bacteria leading to dissolved inorganic carbon production. Among the heterotrophic paths, conversion of calcium lactate (aerobic), urea hydrolysis, and nitrate reduction (anaerobic) by bacterial metabolism are the three main pathways studied intensively by researchers. In the first pathway, crack openings allow oxygen to enter the concrete and bacteria to convert calcium lactate to calcium carbonate and carbon dioxide along cracked surfaces [19]. If there are portlandite crystals in the area, they may create more calcium carbonate with released carbon dioxide, which can also be used for healing. The second path is the precipitation of calcium carbonate by hydrolysis of urea yielding carbonate and ammonium ions [20]. Bacterium Bacillus Sphaericus generate urease as an enzyme that serves as a catalyst. Calcium ion from a calcium source such as calcium nitrate is drawn by a negative bacterial cell to react with the formed carbonate to precipitate calcium carbonate. The third pathway involves reduction of nitrates to produce carbonate and bicarbonate ions under limited oxygen conditions [5]. Urea decomposition and organic 
oxidation by reducing NOx also lead to an increase in $\mathrm{pH}$. Table 1 gives an overview of different bacterial self-healing metabolic pathways.

Table 1 - Bacterial metabolic pathways [21]

\begin{tabular}{|c|c|c|c|c|}
\hline \multicolumn{5}{|c|}{ Heterotrophic Bacteria } \\
\hline Assimilatory & \multicolumn{4}{|c|}{ Dissimilatory pathways } \\
\hline Hydrolysis of urea & \multicolumn{4}{|c|}{ Oxidation of organic carbon } \\
\hline \multirow{2}{*}{$\begin{array}{l}\text { Ammonification of } \\
\text { amino acids }\end{array}$} & Aerobic process & $\mathrm{e}^{-}$acceptor & Anaerobic & $\mathrm{e}^{-}$acceptor \\
\hline & $\begin{array}{c}\text { Respiration } \\
\text { Methane oxidation }\end{array}$ & $\begin{array}{c}\mathrm{O}_{2} \\
\mathrm{CH}_{4} ; \mathrm{O}_{2}\end{array}$ & $\begin{array}{l}\mathrm{NO}_{\mathrm{X}} \text { reduction } \\
\text { Sulfate reduction }\end{array}$ & $\begin{array}{c}\mathrm{NO}_{3}{ }^{-} / \mathrm{NO}_{2}^{-} \\
\mathrm{SO}_{4}{ }^{2-}\end{array}$ \\
\hline
\end{tabular}

Self-healing of bacteria can, therefore, be achieved by all such mechanisms, but the effectiveness of concrete healing will depend on a variety of other factors, including the availability of humidity, cracking surface or width, age of concrete, and bacteria survival in long term conditions. The objective of the study is to review all the available approaches for encapsulating bacteria and its effect on healed crack width followed by various test methods to evaluate the self-healing efficiency and comparative assessment of encapsulation materials and test methods.

\section{2.}

\section{REVIEW}

\subsection{Effect of bacterial encapsulation on crack width}

Efficient self-healing is achieved if the sealing is a long-lasting that can be maintained over a system's lifetime. Therefore, the survival of bacteria is essential. However, if bio-agents are applied directly to concrete, there may be some challenges to the survival of bacteria. Research has shown that the life of untreated spores is limited to only two months when bacterial spores are introduced directly in the mixture and that only young samples have been effectively selfhealed [22]. This may have many reasons, including extreme $\mathrm{pH}$ levels during early-age concrete (high alkalinity) and carbonation phase in matured concrete (high acidic) of the cement matrix, constituents of concrete mixture, and hydration of cement. When spores are long exposed to high alkaline environments, the bacterial response can be significantly reduced. Moreover, some spores may be influenced during mixing by the mixing power or effect of aggregates. Cement hydration lowers the matrix porosity, reducing pores by up to 0.5 $\mu \mathrm{m}$ over time, with typically large bacterial cell size than that of the pores [23]. Thus, shrinking pores at the late stage of a concrete structure will dramatically reduce or avoid cell germination. One way to overcome this restriction is to shield the bacteria without affecting the concrete properties and precipitation of the bacteria. There are specific methods of bacterial encapsulation:

- Encapsulation in polymeric materials - hydrogel, sodium alginate, calcium alginate, rubber particle, melamine microcapsule, silica gel (SG), polyurethane (PU), peroxide tablets $[9,10,11,12,23,25,32,33,34,35]$.

- Encapsulation in lightweight aggregate - expanded clay (EC), Leca aggregates, expanded perlite (EP), ceramsite $[3,4,5,6,7,8,13,22,36,37,39]$.

- Encapsulation in special minerals - diatomaceous earth (DE), zeolite $[13,14,26,38]$ 
- Encapsulation in nanomaterials - graphene nanoplatelets (GNP), granular activated carbon (GAC), iron-oxide nanoparticles (IONPs) [3,13,29,41,42].

- Encapsulation in cementitious materials- Metakaolin-geopolymer coating, limestone powder (LSP), calcium sulphoaluminate powder (CSA), volcanic ash [13,15,30,31,43].

- Encapsulation in waste-derived biomass - biochar [16,17]

Self-healing of cracks increases the toughness of concrete structures through the autogenous healing properties of cemented materials. Nevertheless, the crack width, which can be healed by autogenous self-healing, is only around $0.2 \mathrm{~mm}$, according to previous studies [24]. Increase in the crack width can cause deterioration in the durability due to the penetration of harmful ions inside the concrete. There is, however, no consensus on potential critical crack width for initiation of corrosion [24, 47]. To enhance the strength of concrete, an efficient self-healing strategy is therefore required to cure cracks with widths greater than $0.2 \mathrm{~mm}$.

Numerous encapsulation techniques have been carried out to shield the bacteria from high alkalinity of the cement matrix and increase the healed crack width of the concrete specimens. In polymeric material encapsulation, the maximum crack width of $0.85-0.97 \mathrm{~mm}$ was completely healed by melamine based microcapsules [23] followed by rubber particles that healed a crack width of $0.86 \mathrm{~mm}$ [25]. Similarly, nanomaterials like GNP [3] and biomass from waste-derived sawdust [16] had a maximum completely healed crack width of $0.81 \mathrm{~mm}$ and $0.7 \mathrm{~mm}$, respectively. Encapsulation in lightweight aggregates also healed crack widths greater than $0.1 \mathrm{~mm}$. A maximum crack width of $0.79 \mathrm{~mm}$ was $100 \%$ healed by expanded perlite [8]. Meanwhile, EC had a wide range $(0.15-0.46 \mathrm{~mm})$ of fully healed crack width $[4-6,22]$. In the case of special minerals, the highest crack width of $1.8 \mathrm{~mm}$ was completely healed by DE [26]. This healed crack width was largest in comparison to other encapsulation materials. For some bacterial carriers, the healed crack width was not investigated but their effect on bacterial spores were studied [27-31]. Table 2 represents the type of bacterial carrier used by the authors and the corresponding maximum completely healed crack width. 
Nordic Concrete Research - Publ. No. NCR 62 - ISSUE 1 / 2020 - Article 4, pp. 63-85

Table 2 - Types of Bacterial carrier and the corresponding maximum completely healed crack width

\begin{tabular}{cccc}
\hline Material type & Bacterial Carrier & Maximum healed crack width 100\% (mm) & References \\
\hline & Hydrogel & 0.50 & {$[10],[11]$} \\
Polymers & & 0.34 & {$[12]$} \\
& & 0.25 & {$[32]$} \\
& Sodium alginate & 0.28 & {$[33],[34]$} \\
& Calcium alginate & 0.40 & {$[35]$} \\
& Rubber particle & 0.86 & {$[25]$} \\
& Melamine & $0.85-0.97$ & {$[23]$} \\
\hline \multirow{4}{*}{ LWA } & LWA & 0.61 & {$[3],[36]$} \\
& EC & 0.46 & {$[4],[6]$} \\
& & 0.15 & {$[22]$} \\
& & 0.37 & {$[5],[13]$} \\
& EP & 0.79 & {$[8]$} \\
& Ceramsite & 0.25 & {$[37]$} \\
\hline Nanomaterials & GNP & 0.81 & {$[3]$} \\
\hline \multirow{2}{*}{ Special minerals } & DE & $0.15-0.17$ & {$[38]$} \\
& & 1.80 & {$[26]$} \\
\hline Cementitious & Zeolite & 0.10 & {$[14]$} \\
\hline Biomass & CSA & 0.394 & {$[15]$} \\
& Biochar & 0.70 & {$[17]$} \\
\hline
\end{tabular}

\subsection{Test methods to evaluate self-healing efficiency}

Various testing methods were tested by researchers to study the effects of the crack width and to measure the self-healing. Evaluation of self-healing is a series of multiple assessment that generally includes quantifying the crack closure, recovering one or more engineering characteristics of interest, and qualitative evaluation (characterization of precipitated crystals) of their mutual association. The assessment of healing products further complements the above analysis and helps us understand the essence of healing mechanisms and associated recovery processes. Structural tests are carried out at macro, micro, and nano-scale levels to define a hardened concrete performance criterion. Macrostructure, microstructures, and nanostructure assessments are included. The efficiency of self-healing is evaluated based on these tests presented in Table 3. 
Table 3 - Macro, micro and nano structure test performed for bacteria-based self-healing concrete

\begin{tabular}{|c|c|c|}
\hline Scale of Test & Tests & Best Results $^{1}$ \\
\hline Macrolevel & $\begin{array}{l}\text { Water Permeability; } \\
\text { water absorption, } \\
\text { sorptivity, water } \\
\text { flow, } \mathrm{RCM}^{2}, \mathrm{MIP}^{3} ; \\
\text { flexure; split-tensile; } \\
\text { compression, } \mathrm{LM}^{4}, \mathrm{TAN}^{5}, \\
\mathrm{TGA}^{6}, \mathrm{OPM}^{7}, \\
\text { vicat's test, slump test }\end{array}$ & $\begin{array}{c}98 \% \text { water tightness for LWA bacterial } \\
\text { carrier in curing condition ( } 56 \text { days of wet-dry } \\
\text { cycles) [4]; 59.92\% reduction in chloride ion } \\
\text { permeability for zeolite immobilized bacteria } \\
\text { [14]; } 74 \% \text { increase in compressive strength } \\
\text { for IONP immobilized bacteria [29]; } 72 \% \\
\text { increase in flexural strength for ceramsite } \\
\text { bacterial carriers [39]; } 1.80 \mathrm{~mm} \text { of crack width } \\
\text { healed and visualized by light microscopy } \\
{[26] .}\end{array}$ \\
\hline Microlevel & $\begin{array}{c}\text { FE-SEM }{ }^{8}, \text { EDS }^{9}, \\
\text { X-ray diffraction, } \\
\text { FT-IR }^{10} \text { spectroscopy }\end{array}$ & $\begin{array}{l}\text { Crack surface was fully covered by the } \\
\text { precipitated particles having rectangular and } \\
\text { cubic shapes in bacteria immobilized } \\
\text { hydrogel specimens [32]; presence of calcite, } \\
\text { aragonite and vaterite in GNP immobilized } \\
\text { bacteria [3]; highest peak of } \\
\text { the healing product occurred at } 29.48^{\circ}(2 \theta) \\
\text { corresponding exactly to calcite crystals at } \\
29.45^{\circ}(2 \theta)[16] \text {; different vibrational bands } \\
\text { for calcite were identified in EC immobilized } \\
\text { bacteria [6]. }\end{array}$ \\
\hline Nanolevel & Nanoindentation & $\begin{array}{l}20 \% \text { increase of nano mechanical values of } \\
\text { transition zone. (Interface between } \\
\text { concrete and the deposited material) } \\
\text { compared to the deposited layer [40] }\end{array}$ \\
\hline
\end{tabular}

${ }^{1}$ Best results were in comparison with control specimens without healing agents and bacterial carrier; ${ }^{2}$ Rapid chloride migration; ${ }^{3}$ Mercury intrusion Porosimetry; ${ }^{4}$ Light microscopy; ${ }^{5}$ Nessler's method; ${ }^{6}$ Thermogravimteric analysis; ${ }^{7}$ Oxygen profile measurement; ${ }^{8}$ Scanning electron microscope; ${ }^{9}$ Energy dispersive spectroscopy; ${ }^{10}$ Fourier Transfrom Infrared spectroscopy.

Several macro-scale self-healing efficiency tests were performed. The aim of these tests is to research durability recovery properties, mechanical properties and quantification of precipitated crystals by healing agents. Recovery of durability properties is one of the critical requirements for determining efficiency in self-healing. These measures include -permeability, flow, sorptivity, water absorption, gas permeability, and penetration of the chloride. The comparison between pre-cracked or reference specimens and healed specimens facilitates a simple understanding of the healing process. In comparison, approaches to restoring mechanical properties measure the "structural" behavior of a specimen that plays a dominant part in healed broken specimens. Such assessments involved measurement of mechanical characteristics such as compression, tensile, and flexural characteristics. Closing a crack is the fundamental expression of self-healing and thus the first step to examine and improve the selfhealing process. Surface cracks are the simplest way of quantifying self-healing and are therefore also used to facilitate other research. Some other studies incorporated for assessing the quantification of bacterial activity are thermo-gravimetric analysis (TGA), spectrophotometry (SP), amount of urea decomposed (TAN) and oxygen profile measurement $(\mathrm{OPM})$. Figures 3, 4 and 5 represent the review on macro structure test adopted for encapsulation of bacteria by polymeric materials, lightweight aggregates, nanomaterials, 
cementitious materials, special minerals and biochar in terms of recovery of durability, mechanical properties and quantification of precipitated crystals by healing agent.

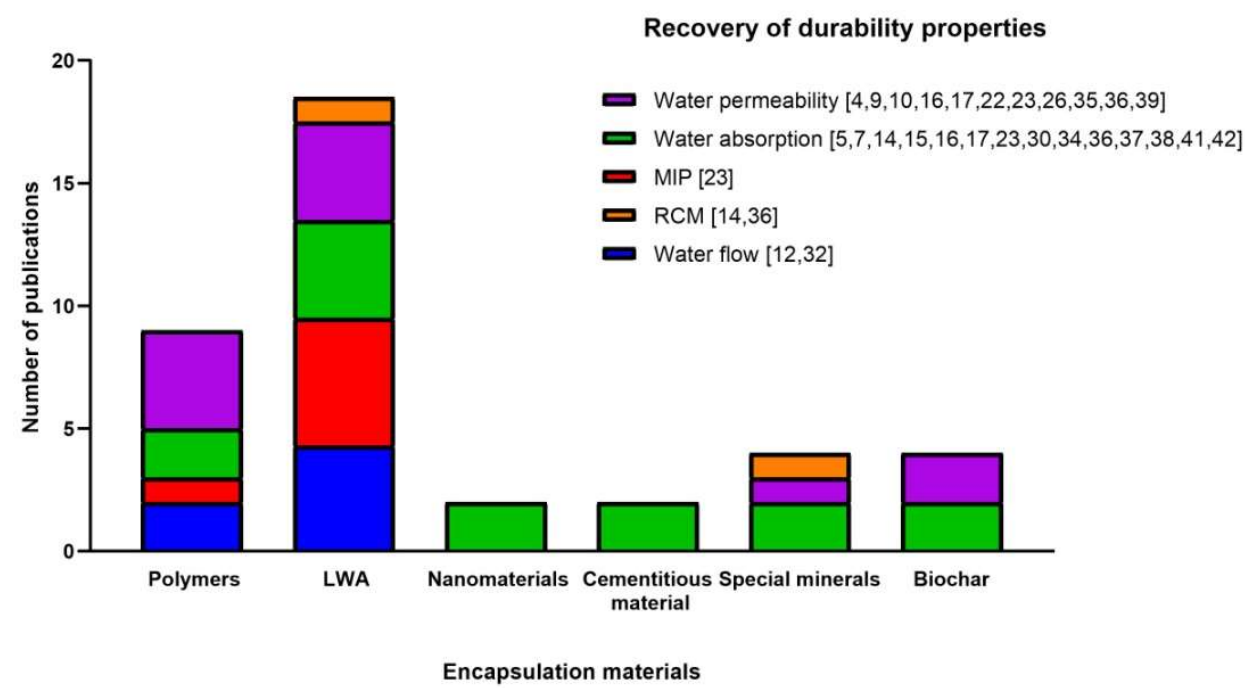

Figure 3 - Tests adopted for recovery of durability properties to determine self-healing.

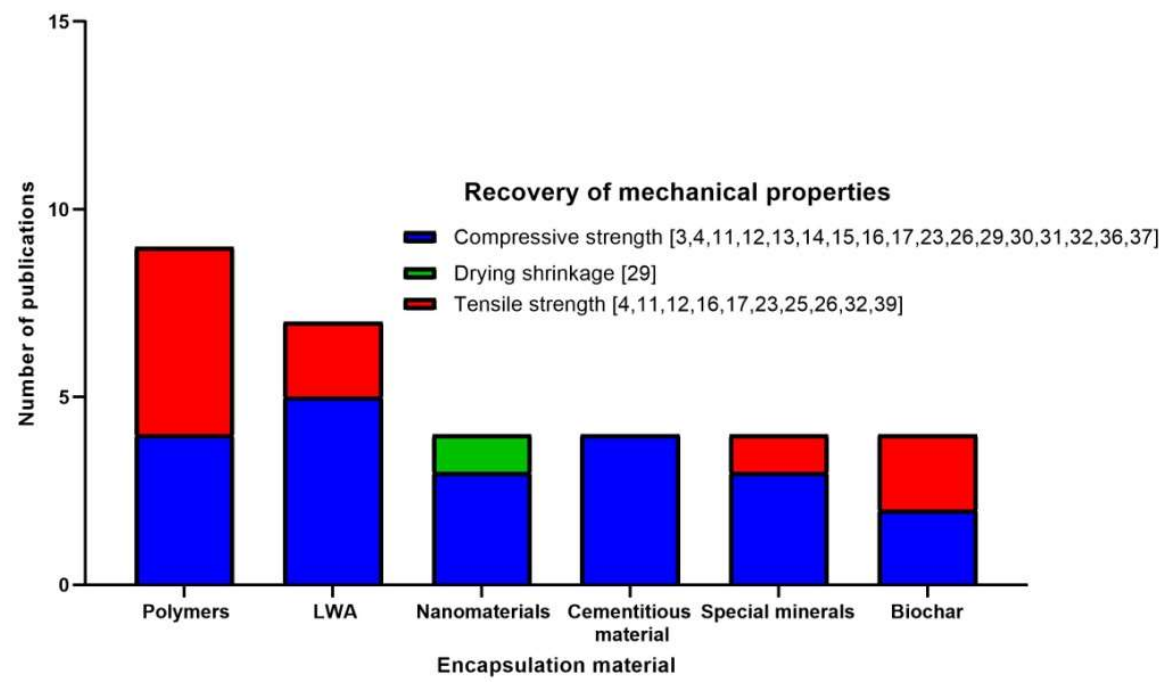

Figure 4 - Tests adopted for recovery of mechanical properties to determine self-healing. 


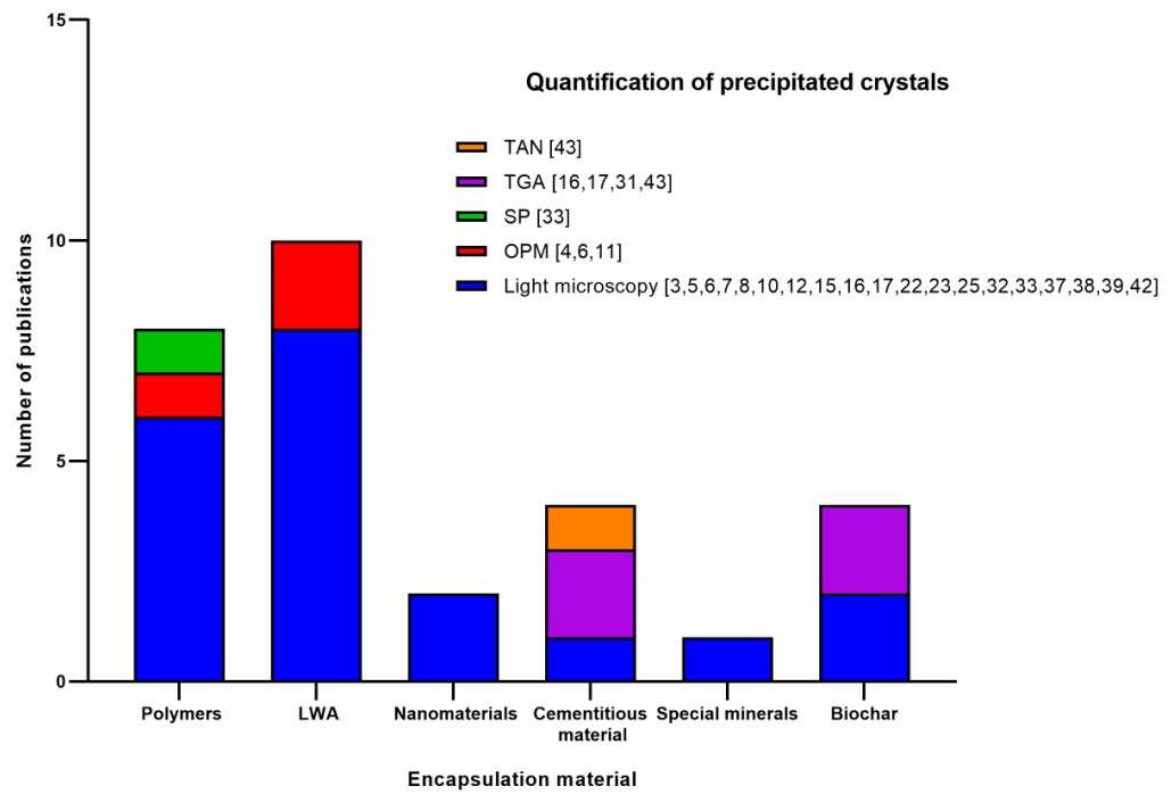

Figure 5 - Tests adopted for quantification of precipitated crystals to determine self-healing.

Figure 3, 4 and 5 shows that most researchers depend on macro-mechanical and durability properties to test the self-healing capacity of polymeric bacterial carriers. On the contrary, many scientists have preferred to quantify the precipitated crystals to determine self-healing for bacterial encapsulation in lightweight aggregates. Test methods based on the recovery of mechanical properties through ultrasonic wave propagation have not been investigated in the field of encapsulation materials in self-healing concrete. In cementitious and biochar materials, quantification of precipitated crystals through TGA has been explored for concrete or mortar samples. Some authors $[5,7,10,22]$ investigated only the durability properties, whereas $[3$, $13,25]$ emphasized only on the mechanical properties. In contrast, the majority of the authors $[4,9,11,12,23,32,35,36,37,39]$ investigated both mechanical and durability properties.

There are few test methods adopted to assess self-healing efficiency of nanomaterials, cementitious materials, special minerals and biochar because the experimental work on the confidence of bacterial carriers in these materials has been limited. The only researcher to examine the assessment of the self-healing efficiency of nanomaterial bacterial carriers in durability and mechanical properties is Seifan [29, 41]. Therefore, further test methods and research on such self-healing bacterial carriers are highly suggested to improve reliability. In the case of encapsulation of cemented materials, durability and mechanical property testing are limited respectively to water absorption and compression testing. On the contrary, several research methods for the quantification of precipitated crystals are performed.

Figures 3, 4 and 5 imply that a wide range of durability tests have been performed for special minerals, while only compression and flexural properties for mechanical characteristics and TGA for quantification of precipitated crystals are tested to determine self-healing. In the research study conducted by Gupta [16-17], both the recovery of durability and mechanical property are studied for bacteria encapsulation in biochar. Besides, not all researchers focused on mechanical and durability testing. Wang [38] emphasized more on durability than Ersan [13], relying solely on mechanical characteristics in special mineral bacterial carriers. To assess the self-healing efficiency of the bacteria-based healing agents, more quantification tests on precipitated crystals should be performed for nanomaterials and special minerals. Preliminary research on evaluating self-healing efficiency of waste-derived biomass encapsulation 
materials has not yet been fully explored. Consequently, in the current ecological crisis, research work on these materials is strongly encouraged to address global warming and climate change.

Microstructure experiments are conducted on a microscale to identify and characterize embedded materials after self-healing. These investigations maximize the reliability of the obtained results. For this purpose, most researchers conduct experiments like scanning electron microscope (SEM), field-emission scanning electron microscope (FESEM), and X-ray diffraction (XRD). Table 10 provides a list of test methods adopted at the microstructural level by the researchers.

Table 10-Microstructure test adopted for encapsulation of bacteria by the bacterial carrier.

\begin{tabular}{|c|c|c|c|c|c|c|}
\hline $\begin{array}{l}\text { Type of test } \\
\text { adopted for } \\
\text { evaluation of } \\
\text { self-healing }\end{array}$ & Polymers & LWA & $\begin{array}{c}\text { Nano- } \\
\text { materials }\end{array}$ & $\begin{array}{c}\text { Special } \\
\text { minerals }\end{array}$ & $\begin{array}{c}\text { Cementitious } \\
\text { materials }\end{array}$ & $\begin{array}{l}\text { Waste } \\
\text { derived } \\
\text { biomass }\end{array}$ \\
\hline $\begin{array}{c}\text { FESEM/SEM + } \\
\text { EDS/EDX }\end{array}$ & $\begin{array}{c}{[10] ;[32] ;} \\
{[35] ;[34] ;} \\
{[9] ;[23]}\end{array}$ & $\begin{array}{c}{[3] ;} \\
{[4] ;[36] ;[5] ;[6]} \\
;[8] ;[39] ;[37]\end{array}$ & $\begin{array}{c}{[29] ;[41] ;} \\
{[42]}\end{array}$ & $\begin{array}{c}{[38] ;[26] ;} \\
{[14]}\end{array}$ & {$[15] ;[31] ;[43]$} & $\begin{array}{l}{[16] ;} \\
{[17]}\end{array}$ \\
\hline XRD & & $\begin{array}{c}{[3] ;[8] ;} \\
{[39] ;[37]} \\
\end{array}$ & [29] & [14] & [15] & {$[16]$} \\
\hline ATR-IR/FT-IR & & {$[5] ;[6]$} & & & & \\
\hline
\end{tabular}

According to Table 10, ATR-IR / FT-IR was the least accepted method of material characterization, followed by XRD. The chemical composition of the precipitate consisting of a calcite and aragonite mixture along with two polymorphs of $\mathrm{CaCO}_{3}$ was reported in ATR-IR $[5,6]$. On the other hand, XRD has often been used as an SEM complementary technique. This approach was used to search the precipitates of confirmed healing agents from macrostructural and SEM examination. SEM analysis was the most common microstructural test carried out by researchers to track precipitation products in crack specimens. Besides, other researchers have merged EDS with SEM for qualitative and quantitative elementary analysis [32, 35]. In addition to the current microstructure level experiments adopted, X-ray tomography, TEM, Raman spectroscopy, and Nuclear Magnet Resonance (NMR) can be used to track and analyze crack healing qualitatively and quantitatively.

Investigation of self-healing efficiency by bacteria encapsulated materials in the nanoscale level has yet to be accomplished. These tests are performed to further maximize the reliability of the results after microstructural tests. It is worth performing nanoscale tests to assess the bonding strength inside the cracks at the interface between the deposited materials and the cement substrate.

\subsection{Comparative assessment of encapsulation materials}

Concrete properties of self-healing concrete are controlled and influenced by different factors, from which mixing proportions and compositions play an essential part in concrete self-healing apart from exposure conditions for curing or healing. The selection and proper use of healing agents are essential to achieve the balance of concrete properties, most economically desirable for a particular concrete mixture. The encapsulation material in the bacteria-based self-healing concrete has a considerable effect on the concrete properties at the fresh and hard state of 
concrete. Fresh concrete characteristics include workability and fundamental rheological properties, slumping loss, setting time, bleeding, segregation, and practical issues in the field of formwork. In contrast, properties of hardened concrete cover compressive strength, tensile strength, elastic properties, shrinkage, creep, cracking resistance, electrical, thermal, transport, and other properties. Hence these effects of encapsulation materials on concrete can play a dominant role in determining the self-healing performance. According to Table 11, polymeric encapsulation materials like hydrogels [11,12], alginates [34,35], and melamine microcapsules [23] have poor mechanical strength recovery. In contrast, other polymeric materials such as rubber particles [25], silica gel and polyurethane [9] have improved effect on compression and flexural strength in reference to original mix composition. LWA encapsulation materials cermasite [37] and IONPs [29] exhibited the maximum improvement in mechanical strength in terms of compression and flexural strength respectively. In the case of durability recovery, almost all encapsulation materials currently under study or have been studied in bacteria-based self-healing concrete have shown promising results. Concrete properties in the fresh state are hardly investigated in bacteria-based self-healing concrete. Tests such as workability do not provide a direct connection with self-healing performance; however, these parameters may play an important role in the consistency of the concrete when healing agents are applied to the mixing process. Research studies revealed that utilization of hydrogels [11] have a negative influence on workability of concrete. Meanwhile, rubber particles [25] and LWA [4] have improved the workability of concrete in comparison to the reference mixture. Some encapsulation materials like powder compression tablets [48] did not have any influence on the workability and mechanical properties of concrete but the durability of the concrete improved significantly.

There is generally lack of data on the quality criteria for the selection of encapsulation material for bacterial self-healing. The quality criteria can depend on various factors such as good biocompatibility of the material, bacterial cell entrapping property, moisture retention or water storage capacity for the immobilized bacterial metabolism, environmental friendly in usage, cost-effective for large-scale operations, tolerant in extreme $\mathrm{pH}$ levels, uniform distribution of the bacterial spores, monodispersity of the encapsulation material, simple encapsulation procedure and ways to mitigate climate change by improving waste management and reducing toxic emissions. Therefore, a comparative assessment of the encapsulation materials in terms of the pros and cons of their use in self-healing concrete would be useful for the selection of encapsulation materials. Also sustainability assessment methods, such as life-cycle assessment can be applied to study and improve the life-cycle environmental impacts of adopting an encapsulation material for concrete healing applications. Table 11 enlists the pros and cons of each encapsulation materials investigated for bacterial self-healing.

Table 11 -Comparative assessment of encapsulation materials. A summary of effect on concrete properties, pros and cons of various encapsulation materials used in bacteria-based self healing concrete. The concrete properties are addressed in reference to control samples without healing agents" $\uparrow "$ denotes an \% increase, " $\downarrow$ " a \% decrease and"-" no \% change in reviewed properties . "N/A"refers to data unavailable.

\begin{tabular}{|c|c|c|c|c|c|c|c|c|c|c|}
\hline \multicolumn{4}{|c|}{ Healing agents } & \multirow{2}{*}{$\begin{array}{l}\text { Exposure condition for } \\
\text { crack-healing }\end{array}$} & \multicolumn{2}{|c|}{ Bacterial Carrier } & \multicolumn{2}{|c|}{$\begin{array}{l}\text { Concrete } \\
\text { properties }\end{array}$} & \multirow{2}{*}{$\begin{array}{c}\text { Avg. } \\
\text { Healing } \\
\text { Ratio }\end{array}$} & \multirow[t]{2}{*}{ Ref. } \\
\hline Bacteria & $\begin{array}{l}\text { Bacterial } \\
\text { carrier }\end{array}$ & Nutrients & $\begin{array}{l}\text { Precursor } \\
\text { salts }\end{array}$ & & Pros & Cons & $\begin{array}{l}\text { Fresh } \\
\text { state }\end{array}$ & $\begin{array}{l}\text { Hard } \\
\text { state }\end{array}$ & & \\
\hline $\begin{array}{c}\text { Bacillus } \\
\text { Sphaericus }\end{array}$ & $\begin{array}{l}\text { Modified } \\
\text { alginate } \\
\text { hydrogel }\end{array}$ & YE, urea & $\begin{array}{l}\text { Calcium } \\
\text { nitrate }\end{array}$ & Full immersion in water & & $\begin{array}{l}\text { Absorb w } \\
\text { in hard sta } \\
\text { creating } \\
\text { macropor }\end{array}$ & $\mathrm{W}^{6}(\downarrow)$ & $\begin{array}{l}\mathrm{WA}^{7} 47(\downarrow) \\
\text { CS } 23(\downarrow) \\
\text { FS } 30(\downarrow)\end{array}$ & N.A & {$[11]$} \\
\hline
\end{tabular}


Nordic Concrete Research - Publ. No. NCR 62 - ISSUE 1 / 2020 - Article 4, pp. 63-85

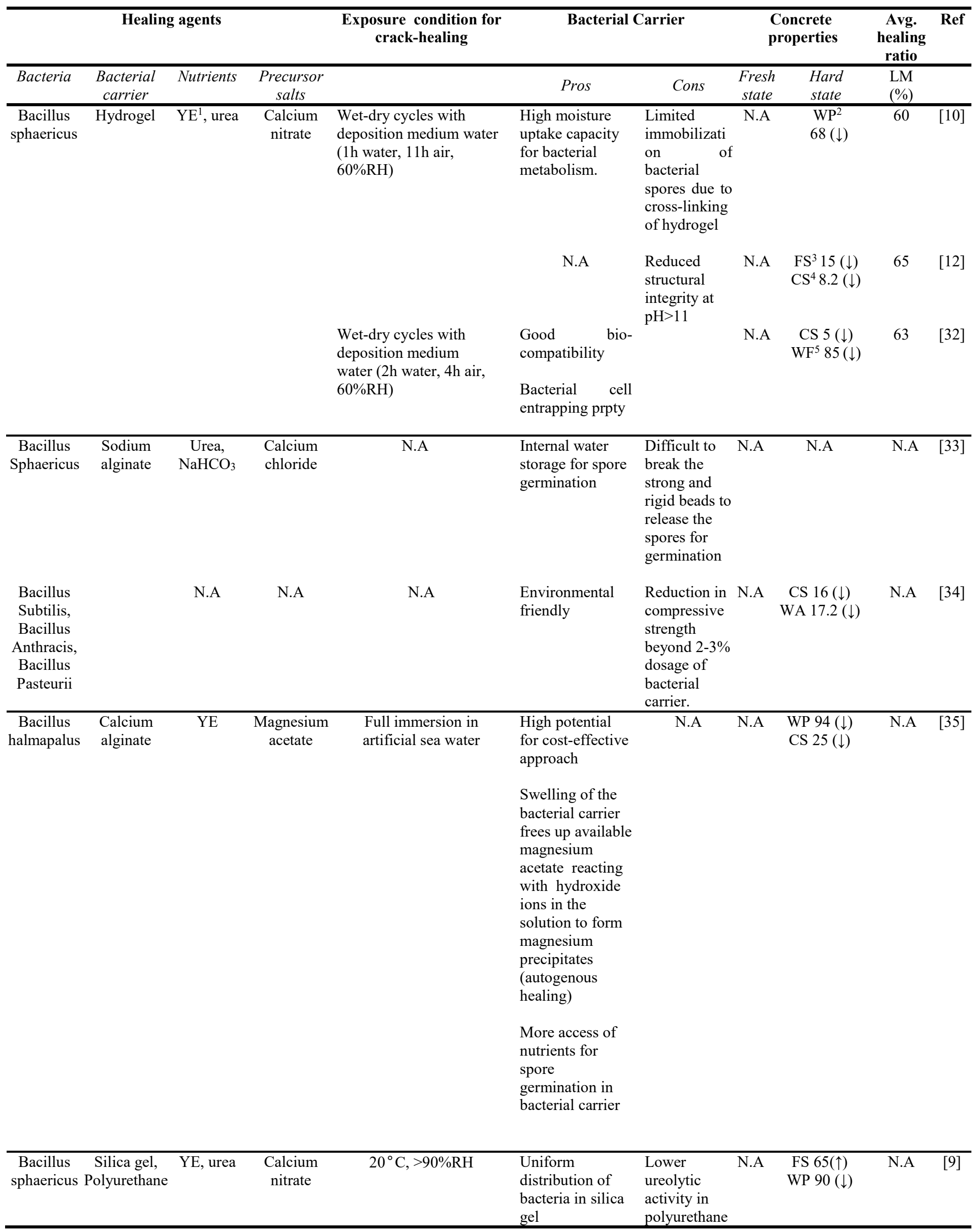


Nordic Concrete Research - Publ. No. NCR 62 - ISSUE 1 / 2020 - Article 4, pp. 63-85

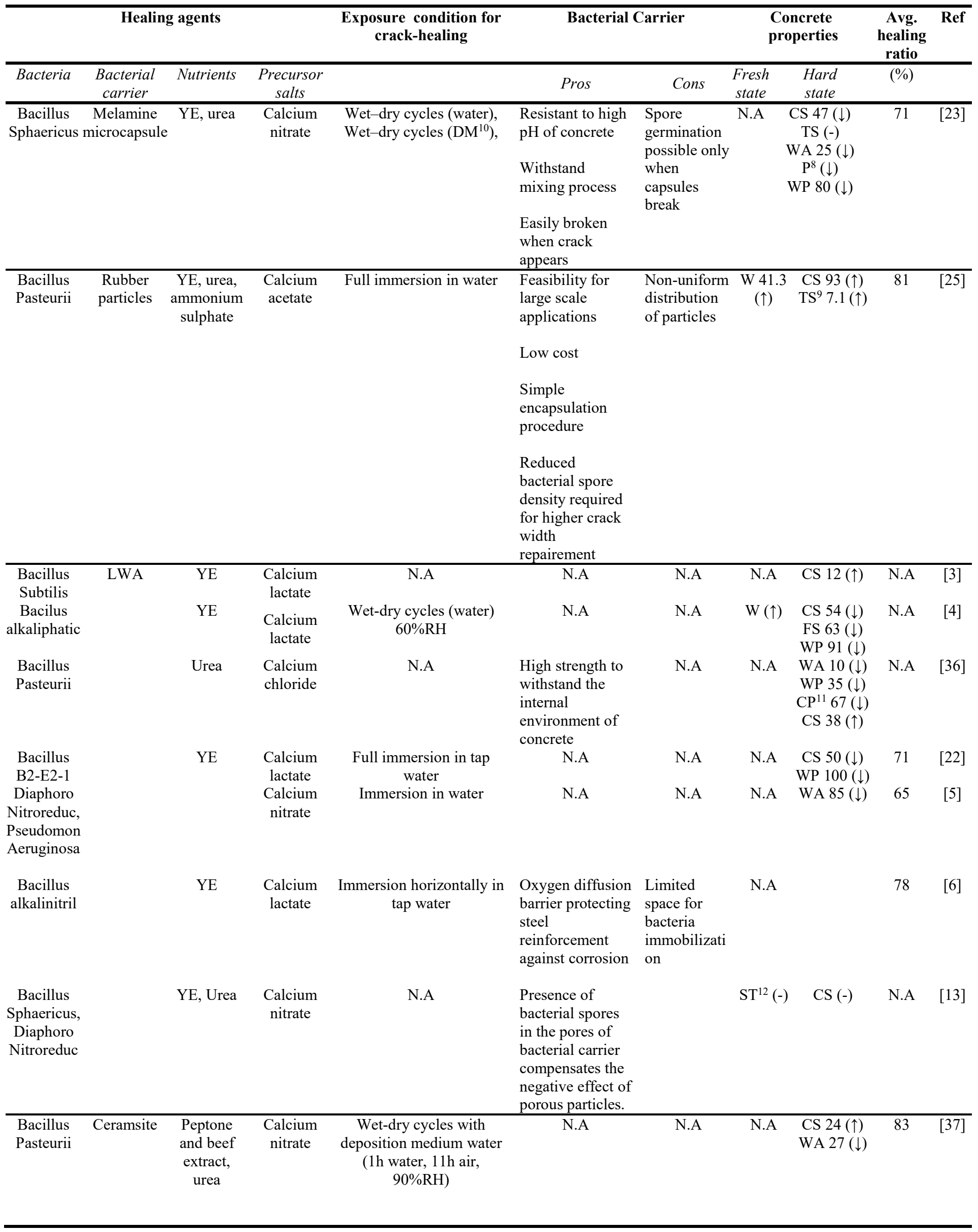


Nordic Concrete Research - Publ. No. NCR 62 - ISSUE 1 / 2020 - Article 4, pp. 63-85

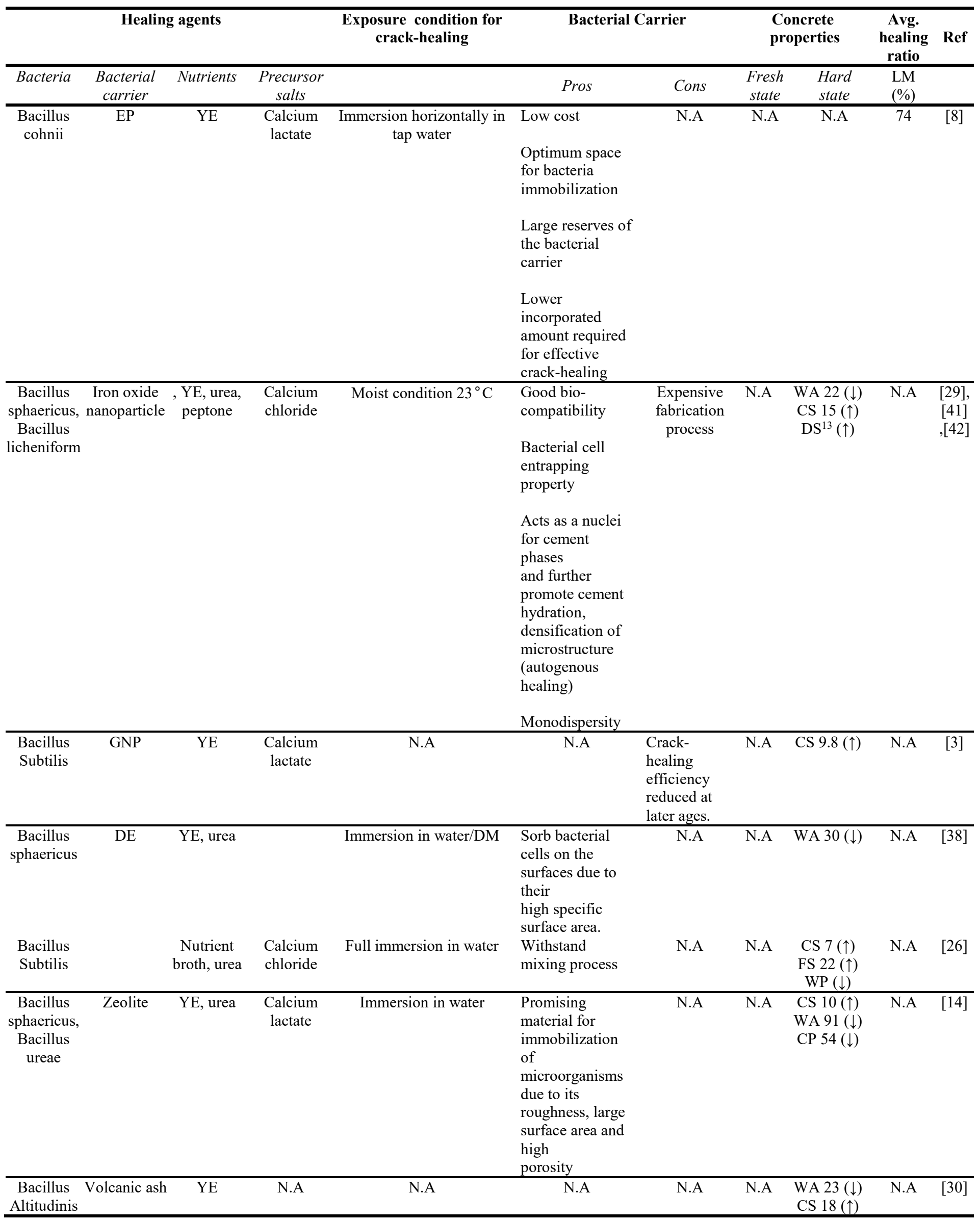


Nordic Concrete Research - Publ. No. NCR 62 - ISSUE 1 / 2020 - Article 4, pp. 63-85

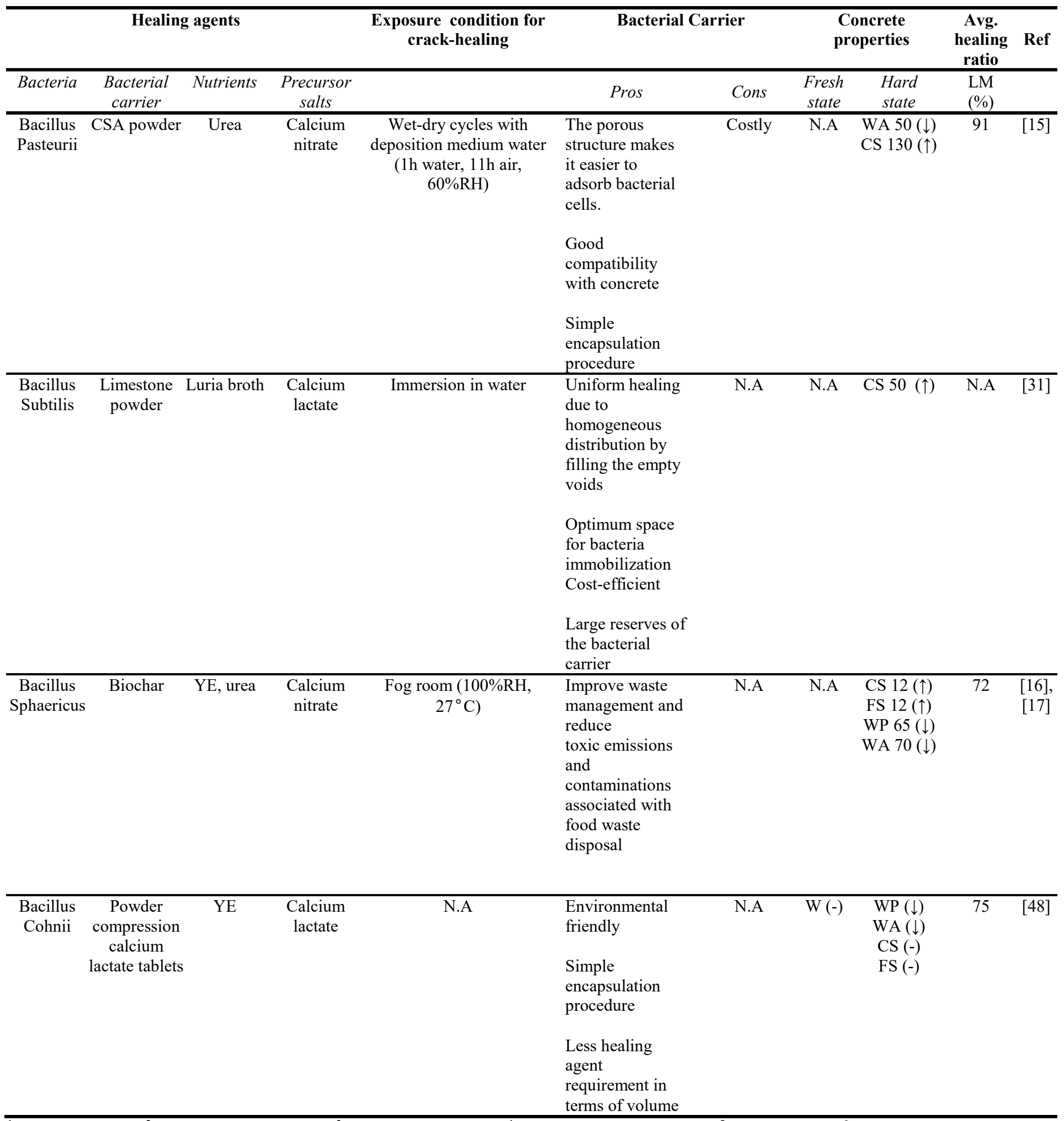

${ }^{1}$ Yeast extract; ${ }^{2}$ Water permeability, ${ }^{3}$ Flexural strength, ${ }^{4}$ Compression strength, ${ }^{5}$ Water flow; ${ }^{6}$ Workability; ${ }^{7}$ Water absorption; ${ }^{8}$ Porosity; ${ }^{9}$ Split-tensile; ${ }^{10}$ Solution composed of urea and calcium nitrate; ${ }^{11}$ Chloride penetration; ${ }^{12}$ Setting time; ${ }^{13}$ Drying shrinkage 


\subsection{Comparative assessment of test methods}

To choose appropriate test methods for assessing self-healing efficiency depends on the researcher's goal and hypothesis of their investigation. During a research investigation, it is essential to conduct an extensive literature review to formulate a standardized framework for testing the self-healing efficiency of concrete. Thus a comparative assessment of test methods adopted from the literature concerning the limitations can assist in shaping the researcher's objective of performing the investigation. Table 12 provides a summary of the test methods adopted to assess self-healing efficiency with their advantages and limitations of performing the desired test.

Table 12 - Comparative assessment of test methods in terms of pros and cons

\begin{tabular}{|c|c|c|c|}
\hline $\begin{array}{l}\text { Type of test } \\
\text { adopted for } \\
\text { evaluation of self- } \\
\text { healing }\end{array}$ & Test & Pros & Cons \\
\hline \multirow[t]{3}{*}{$\begin{array}{l}\text { Quantification of } \\
\text { crack healing }\end{array}$} & $\begin{array}{c}\text { Light } \\
\text { microscopy }\end{array}$ & $\begin{array}{l}\text {-Inexpensive and } \\
\text { convenient to implement. } \\
\text {-Simple sample } \\
\text { preparation. } \\
\text {-Surface crack } \\
\text { representation seen by the } \\
\text { eye, but with better } \\
\text { resolution and natural } \\
\text { colours. } \\
\text {-Visualization of a wider } \\
\text { region } \\
\text { - Better results for crack } \\
\text { width range } 0.2-0.7\end{array}$ & $\begin{array}{l}\text {-In general, a certain } \\
\text { distance is required to } \\
\text { cover the entire specimen. } \\
\text {-Can not determine } \\
\text { precipitation composition } \\
\text {-Can not measure internal } \\
\text { crack width }\end{array}$ \\
\hline & TGA & $\begin{array}{l}\text {-Identifies the precipitated } \\
\text { products by healing agents } \\
\text { in cracked surfaces } \\
\text {-Identifies the various } \\
\text { phases present in the self- } \\
\text { healing concrete } \\
\text {-Quantifies the hydration } \\
\text { reactions }\end{array}$ & $\begin{array}{l}\text { - Prepared samples must be } \\
\text { free from physically } \\
\text { bounded water. } \\
\text {-Do not provide conclusive } \\
\text { minerological or } \\
\text { compositional identification } \\
\text { on its own. } \\
\text { - Need to be suplemented } \\
\text { with other material } \\
\text { characterization techniques } \\
\text { like XRD. } \\
\text { - Result interpretation } \\
\text { sensitive to paramters uch } \\
\text { as amount of sample, } \\
\text { heating rate, type of gas } \\
\text { and gas flow rate used. }\end{array}$ \\
\hline & OPM & $\begin{array}{l}\text {-Can differentiate biogenic } \\
\mathrm{CaCO}_{3} \text { from abiotic } \mathrm{CaCO}_{3} \\
\text { - Able to determine the } \\
\text { bacterial metabolic activity }\end{array}$ & $\begin{array}{l}\text { - Insufficient data to } \\
\text { incorporate for large scale } \\
\text { applications }\end{array}$ \\
\hline
\end{tabular}


Nordic Concrete Research - Publ. No. NCR 62 - ISSUE 1 / 2020 - Article 4, pp. 63-85

\begin{tabular}{|c|c|c|c|}
\hline $\begin{array}{c}\text { Type of test } \\
\text { adopted for } \\
\text { evaluation of self- } \\
\text { healing } \\
\end{array}$ & Test & Pros & Cons \\
\hline \multirow[t]{3}{*}{$\begin{array}{c}\text { Recovery of } \\
\text { durability } \\
\text { property }\end{array}$} & $\begin{array}{c}\text { Water } \\
\text { permeability }\end{array}$ & $\begin{array}{l}\text {-The coefficient of water } \\
\text { permeability can be } \\
\text { determined by the water } \\
\text { flow through healed cracks }\end{array}$ & $\begin{array}{l}\text {-Efficacy relies on the way } \\
\text { cracks have been } \\
\text { introduced }\end{array}$ \\
\hline & $\begin{array}{c}\text { Water } \\
\text { absorption }\end{array}$ & $\begin{array}{l}\text {-Determines the ability of } \\
\text { concrete to absorb and } \\
\text { transmit liquid via capillary } \\
\text { suction }\end{array}$ & $\begin{array}{l}\text { - Requires a reference } \\
\text { source for comparison as } \\
\text { water is absorbed from the } \\
\text { undamaged matrix. }\end{array}$ \\
\hline & $\begin{array}{l}\text { Chloride } \\
\text { penetration }\end{array}$ & $\begin{array}{l}\text {-Determines the materials } \\
\text { resistance ability against } \\
\text { chloride penetration. }\end{array}$ & $\begin{array}{l}\text { - Creatio of larger crack } \\
\text { widths for determining the } \\
\text { healing efficieny in RCM } \\
\text { samples are troublesome }\end{array}$ \\
\hline \multirow[t]{3}{*}{$\begin{array}{l}\text { Recovery of } \\
\text { mechanical } \\
\text { property }\end{array}$} & $\begin{array}{l}\text { Compression } \\
\text { Strength }\end{array}$ & $\begin{array}{l}\text {-Determines the recovery of } \\
\text { mechanical strength due to } \\
\text { self-healing. }\end{array}$ & $\begin{array}{l}\text { - Test results are sensitive } \\
\text { to concrete mixing, curing } \\
\text { and handling of specimens }\end{array}$ \\
\hline & $\begin{array}{l}\text { Flexural } \\
\text { strength }\end{array}$ & $\begin{array}{l}\text {-Implementable for large } \\
\text { scale applications } \\
\text {-Basic quality control }\end{array}$ & $\begin{array}{l}\text { - Do not provide complete } \\
\text { information on self-healing } \\
\text { performace }\end{array}$ \\
\hline & $\begin{array}{l}\text { Split-tensile } \\
\text { strength }\end{array}$ & $\begin{array}{l}\text { testing for industrial } \\
\text { applications }\end{array}$ & $\begin{array}{l}\text {-Uncertainity of test results } \\
\text { from a measured core } \\
\text { strength as being truely } \\
\text { representative of the in- } \\
\text { place strength. } \\
\text {-Evaluation of self-healing } \\
\text { is determined only on the } \\
\text { basis of strength and not } \\
\text { durability }\end{array}$ \\
\hline \multirow[t]{3}{*}{$\begin{array}{l}\text { Characterization } \\
\text { of healing agent } \\
\text { products }\end{array}$} & SEM & $\begin{array}{l}\text { - Visualization of crystal } \\
\text { deposited for healing }\end{array}$ & $\begin{array}{l}\text { - Precision and } \\
\text { visualization depend on the } \\
\text { location and resolution of } \\
\text { images used } \\
\text { - Information on uniform } \\
\text { carbonate deposition can } \\
\text { not be collected using this } \\
\text { process }\end{array}$ \\
\hline & FT-IR & $\begin{array}{l}\text {-Rapid material } \\
\text { characterization technique } \\
\text {-Identfies different modes } \\
\text { of vibration of the } \\
\text { hydration products }\end{array}$ & $\begin{array}{l}\text { - Responsive to concrete } \\
\text { moisture content } \\
\text { - Minor deposition may not } \\
\text { be noticed because only } \\
\text { significant deposition is } \\
\text { recorded in this method }\end{array}$ \\
\hline & XRD & $\begin{array}{l}\text {-Rapid detection of } \\
\text { crystalline compounds } \\
\text {-Resembalation of calcite in } \\
\text { XRD database }\end{array}$ & $\begin{array}{l}\text {-Difficult to quantify } \\
\text { calcium carbonate } \\
\text { precipitation } \\
\text { - Do not allow detection of }\end{array}$ \\
\hline
\end{tabular}




\section{CONCLUSIONS AND SCOPE OF FUTURE WORK}

\subsection{Conclusions}

The importance of this work is to identify the common test methodologies adopted to assess the self-healing efficiency of bacteria-based healing agents and types of encapsulation materials currently present for bacteria. Based on the previous studies, the most common approaches to encapsulate bacteria are polymers and lightweight aggregates. The study has also identified that the maximum crack width healed is around $1.8 \mathrm{~mm}$ by encapsulation in diatomaceous earth. Furthermore, lightweight aggregates and nanomaterials have a positive effect on the mechanical properties of the concrete in contrast to other encapsulation materials. The common characteristic of bacteria-based healing agents was the recovery of durability properties like the decrease in water absorption and increased resistance to chloride permeability. The recovery of mechanical properties was the most common macrostructural test adopted by the majority of the researchers, followed by durability and quantification of precipitated crytals. To quantify crack-healing, LM was the most adopted bacterial quantification technique. In contrast, TGA was the least quantification technique adopted according to the literature. Some researchers have even conducted tests on microstructure level in addition to macrostructure to maximize the verification of the results. SEM was the most popular technique adopted among the researchers for verifying the precipitated crystals by healing agents followed by XRD. The authors have not found anyone having conducted tests on nanostructure level for encapsulated bacteria. From the performed literature review, suitable test methodologies for evaluating self-healing efficiency of novel bacteria-based healing agents have been selected. To evaluate the self-healing efficiency of novel bacteria based healing agent, durability tests on permeability and water absorption can be conducted on laboratory scale to determine the flow of water through healed cracks followed by quantification and visualization of the crack healing by TGA and LM. In order to confirm the reliability of the results, microstructural tests like SEM, XRD or FT-IR can be adopted to identify and characterize the presence of precipitated products in the crack specimens.

\subsection{Future research}

Powder compression allows the development of particles with healing agents composed almost entirely of ingredients that can be used for healing. This type of healing agent, therefore, needs much less volumetric healing agent than light porous particles, which is highly advantageous because a pore particle-based healing agent does not reduce concrete strength $[3,4,13]$. A characteristic of these powders is water solubility, which facilitates matrix cracking and water absorption, dispersing the healing agent in crack volume. These scalable particles are consisting almost entirely of active ingredients produced by roller compacting the healing agent to thin wafers by applying heat, then milling these wafers into powders that are sieved to obtain a sand-size range $(0.5-1 \mathrm{~mm})$. In addition to the following procedure, a freeze-drying method is adopted to eliminate the obtained powder viscosity. In the encapsulation process, the active 
ingredients include bacterial spores (aerobic bacteria-Bacillus Cohnii), nutrients (yeast extract), and carbon substrates (calcium lactate or biodegradable plastic derivatives). According to Jonkers [44], calcium lactate derivates produces six equivalents of $\mathrm{CaCO}_{3}$ from one equivalent of calcium lactate derivatives. Besides, biodegradable plastic based derivatives are used as a bacterial precursor and an alternative for calcium lactate derivatives to introduce materials that could serve as a self-healing agent and provide a new avenue for waste management. A significant volume of carbon dioxide is used during the growth phase to manufacturing these products, and its emissions are equal to 20 percent of petrochemical plastics [45]. Hence the utilization of these low-carbon plastics would help regulate the earth's temperature rise [46]. Moreover, the degradation of these bio-plastics produces non-toxic substances like water and carbon dioxide, making it an environmental-friendly material.

\section{REFERENCES}

1. Rajczakowska M, Habermehl-Cwirzen K, Hedlund H \& Cwirzen A: "Autogenous selfhealing: A better solution for concrete". Journal of Materials in Civil Engineering, V. 31, No. 9, 2019. 03119001-03119001. doi:10.1061/(ASCE)MT.1943-5533.0002764.

2. Mahmoodi S \& Sadeghian P: "Self-healing concrete: A review of recent research developments and existing research gaps". Proceedings, Annual Conference - Canadian Society for Civil Engineering, June, 2019.

3. Khaliq W \& Ehsan M: "Crack healing in concrete using various bio influenced selfhealing techniques". Construction and Building Materials: Part 1, V. 102, 2016, pp. 349-357. doi:10.1016/j.conbuildmat.2015.11.006.

4. Tziviloglou E, Wiktor V, Jonkers H \& Schlangen E: "Bacteria-based self-healing concrete to increase liquid tightness of cracks". Construction and Building Materials, V. 122, 2016, pp. 118-125. doi:10.1016/j.conbuildmat.2016.06.080.

5. Erşan Y, Hernandez-Sanabria E, Boon N \& De Belie N: "Enhanced crack closure performance of microbial mortar through nitrate reduction". Cement and Concrete Composites, V. 70, 2016, pp. 159-170. doi:10.1016/j.cemconcomp.2016.04.001.

6. Wiktor V \& Jonkers H: "Quantification of crack-healing in novel bacteria-based selfhealing concrete". Cement and Concrete Composites, V. 33, No. 7, 2011, pp. 763-770. doi:10.1016/j.cemconcomp.2011.03.012.

7. Alazhari M, Sharma T, Heath A, Cooper R \& Paine K: "Application of expanded perlite encapsulated bacteria and growth media for self-healing concrete". Construction \& Building Materials, V. 160, 2018, pp. 610-619.

8. Zhang J, Liu Y, Feng T, Zhou M, Zhao L, Zhou A, \& Li Z: "Immobilizing bacteria in expanded perlite for the crack self-healing in concrete". Construction and Building Materials, V. 148, 2017, pp. 610-617. doi:10.1016/j.conbuildmat.2017.05.021.

9. Wang J, Van Tittelboom K, De Belie N \& Verstraete W: "Use of silica gel or polyurethane immobilized bacteria for self-healing concrete". Construction and Building Materials, V. 26, No. 1, 2012, pp. 532-540. doi:10.1016/j.conbuildmat.2011.06.054.

10. Wang J, Snoeck D, Van Vlierberghe S, Verstraete W \& De Belie N.: "Application of hydrogel encapsulated carbonate precipitating bacteria for approaching a realistic selfhealing in concrete". Construction and Building Materials, V. 68, 2014, pp. 110-119. doi:10.1016/j.conbuildmat.2014.06.018.

11. Jianyun E, Arn E, Didier E, Virginie E, Nico E \& Nele E: “Application of modifiedalginate encapsulated carbonate producing bacteria in concrete: A promising strategy for crack self-healing”. Frontiers in Microbiology, 2015. doi:10.3389/fmicb.2015.01088. 
12. Trenson G: "Application of $\mathrm{pH}$ responsive hydrogel encapsulated bacteria for selfhealing concrete". Doctoral Thesis, Ghent Univ., Ghent, Belgium.

13. Erşan Y, Da Silva F, Boon N, Verstraete W \& De Belie N: "Screening of bacteria and concrete compatible protection materials". Construction and Building Materials, V. 88, 2015, pp. 96-203. doi:10.1016/j.conbuildmat.2015.04.027.

14. Bhaskar S, Anwar Hossain K, Lachemi M, Wolfaardt G \& Otini Kroukamp M: "Effect of self-healing on strength and durability of zeolite-immobilized bacterial cementitious mortar composites". Cement and Concrete Composites, V. 82, 2017, pp. 23-33. doi:10.1016/j.cemconcomp.2017.05.01

15. Xu J \& Wang X: "Self-healing of concrete cracks by use of bacteria-containing low alkali cementitious material". Construction and Building Materials, V. 167, 2018, pp. 1-14. doi:10.1016/j.conbuildmat.2018.02.020.

16. Gupta S, Kua H \& Pang S: "Healing cement mortar by immobilization of bacteria in biochar: An integrated approach of self-healing and carbon sequestration". Cement and Concrete Composites, V. $\quad 86, \quad 2018, \quad$ pp. 238-254. doi:10.1016/j.cemconcomp.2017.11.015.

17. Kua H, Gupta S, Aday A, \& Srubar W: "Biochar-immobilized bacteria and superabsorbent polymers enable self-healing of fiber-reinforced concrete after multiple damage cycles". Cement and Concrete Composites, V. 100, 2019, pp. 35-52. doi:10.1016/j.cemconcomp.2019.03.017.

18. Hammes $\mathrm{F} \&$ Verstraete $\mathrm{W}$ : "Key roles of $\mathrm{pH}$ and calcium metabolism in microbial carbonate precipitation". Reviews in Environmental Science and Biotechnology, V. 1, No. 1, 2002, pp. 3-7. doi:10.1023/A:1015135629155.

19. Schlangen E \& Jonkers H: "A two component bacteria-based self-healing concrete". Concrete Repair, Rehabilitation \& Retrofitting II, 2008, pp. 119-120. doi:10.1201/9781439828403.ch27.

20. Van Tittelboom K, De Belie N, De Muynck W \& Verstraete W: 'Use of bacteria to repair cracks in concrete". Cement and Concrete Research, V. 40, No. 1, 2010, pp. 157-166. doi:10.1016/j.cemconres.2009.08.025.

21. De Belie N \& Wang J: "Bacteria-based repair and self-healing of concrete". Journal of Sustainable Cement-Based Materials, V. 5, No. 1-2, 2016, pp. 35-56. doi:10.1080/21650373.2015.1077754.

22. Jonkers H: "Bacteria-based self-healing concrete". Heron - English Edition, V. 56, No. 1-2, 2011, pp. 1-12.

23. Wang J, Soens H, Verstraete W \& De Belie N: "Self-healing concrete by use of microencapsulated bacterial spores". Cement and Concrete Research, V. 56, 2014, pp. 139-152.

24. Danner T \& Geiker M R: "Mineralogical sequence of self-healing products in cracked marine concrete". Minerals, V. 9 No. 5, 2019. https://doi.org/10.3390/min9050284

25. $\mathrm{Xu} \mathrm{H}$, Lian J, Gao M, Fu D \& Yan Y: "Self-healing concrete using rubber particles to immobilize bacterial spores". Materials, V. 12, No. 14, 2019. doi:10.3390/ma12142313.

26. Huynh N, Phuong N, Toan N \& Son N: "Bacillus subtilis hu58 immobilized in micropores of diatomite for using in self-healing concrete". Procedia Engineering, V. 171, 2017, pp. 598-605. doi:10.1016/j.proeng.2017.01.385.

27. Jinlong Z, Bixia M, Tingwei C, Jiayi L, Wanhan W, Bing L \& Xu D: "Optimization of a binary concrete crack self-healing system containing bacteria and oxygen". Materials, V. 10, No. 2, 2017. doi:10.3390/ma10020116.

28. Zhang J, Wang C, Wang Q, Feng J, Pan W, Zheng X \& Deng X: “A binary concrete crack self-healing system containing oxygen-releasing tablet and bacteria and its ca2 - 
precipitation performance". Applied Microbiology and Biotechnology, V. 100, No. 24, 2016, pp. 10295-10306.

29. Seifan M, Sarmah A, Ebrahiminezhad A \& Ghasemi Y: "Mechanical properties of bio self-healing concrete containing immobilized bacteria with iron oxide nanoparticles". Applied Microbiology and Biotechnology, V. 102, No. 10, 2018, pp. 4489-4498. doi:10.1007/s00253-018-8913-9.

30. Purwanto H, Nugroho A \& Aprilin S: "Study of volcanic-ash-impregnated-bacteria filler to the compressive strength of concrete". Proceedings, Matec Web of Conferences, 138, 2017. doi:10.1051/matecconf/201713801014.

31. Nafeesa S, Rao A \& Siraj U: "Bioimmobilized limestone powder for autonomous healing of cementitious systems: A feasibility study". Advances in Materials Science and Engineering, 2018. doi:10.1155/2018/7049121.

32. Wang J, Mignon A, Trenson G, Van Vlierberghe S, Boon N \& De Belie N: "A chitosan based ph-responsive hydrogel for encapsulation of bacteria for self-sealing concrete". Cement and Concrete Composites, V. 93, 2018, pp. 309-322. doi:10.1016/j.cemconcomp.2018.08.007.

33. Wiboonluk P, Jirapa I, Pitcha J \& Suched L: "Evaluation of microencapsulation techniques for micp bacterial spores applied in self-healing concrete". Scientific Reports, V. 9, No. 1, 2019, pp. 1-10. doi:10.1038/s41598-019-49002-6.

34. Shahid S, Aslam M, Ali S, Zameer M \& Faisal M: "Self-healing of cracks in concrete using bacillus strains encapsulated in sodium alginate beads". Chemistryselect, V. 5, No. 1, 2020, pp. 312-323. doi:10.1002/slct.201902206.

35. Palin D, Wiktor $\mathrm{V} \&$ Jonkers $\mathrm{H}$ M: "A bacteria-based self-healing cementitious composite for application in low-temperature marine environments". (2017). Biomimetics, V. 2, No. 4, 2017, p. 13. doi:10.3390/biomimetics2030013.

36. Hosseini Balam N, Mostofinejad D \& Eftekhar M: "Effects of bacterial remediation on compressive strength, water absorption, and chloride permeability of lightweight aggregate concrete". Construction and Building Materials, V. 145, 2017, pp. 107-116. doi:10.1016/j.conbuildmat.2017.04.003.

37. $\mathrm{Xu} \mathrm{J}$, Wang X \& Wang B: "Biochemical process of ureolysis-based microbial caco3 precipitation and its application in self-healing concrete". Applied Microbiology and Biotechnology, V. 102, No. 7, 2018, pp. 3121-3132. doi:10.1007/s00253-018-8779-x.

38. Wang J, De Belie N \& Verstraete W: "Diatomaceous earth as a protective vehicle for bacteria applied for self-healing concrete". Journal of Industrial Microbiology \& Biotechnology, V 39, No. 4, 2012, pp. 567-77. doi:10.1007/s10295-011-1037-1.

39. Chen H, Qian C \& Huang H: "Self-healing cementitious materials based on bacteria and nutrients immobilized respectively". Construction and Building Materials, V. 126, 2016, pp. 297-303. doi:10.1016/j.conbuildmat.2016.09.023.

40. $\mathrm{Xu} \mathrm{J} \&$ Yao W: "Multiscale mechanical quantification of self-healing concrete incorporating non-ureolytic bacteria-based healing agent". Cement and Concrete Research, V. 64, 2014, pp. 1-10. doi:10.1016/j.cemconres.2014.06.003.

41. Seifan M, Ebrahiminezhad A, Ghasemi Y \& Berenjian A: "Microbial calcium carbonate precipitation with high affinity to fill the concrete pore space: Nanobiotechnological approach". Bioprocess and Biosystems Engineering, V. 42, No. 1, 2019, pp. 37-46. doi:10.1007/s00449-018-2011-3.

42. Seifan M, Sarmah A, Ebrahiminezhad A \& Ghasemi Y: "Bio-reinforced self-healing concrete using magnetic iron oxide nanoparticles". Applied Microbiology and Biotechnology, 102(5), V. 102, No. 5, 2018, pp. 2167-2178. doi:10.1007/s00253-0188782-2. 
43. Jadhav U, Lahoti M, Chen Z, Qiu J, Cao B \& Yang E: "Viability of bacterial spores and crack healing in bacteria-containing geopolymer". Construction and Building Materials, V. 169, 2018, pp. 716-723. doi:10.1016/j.conbuildmat.2018.03.039.

44. Jonkers H, Thijssen A, Muyzer G, Copuroglu O \& Schlangen E: "Application of bacteria as self-healing agent for the development of sustainable concrete". Ecological Engineering, 36(2), V 36, No. 2, 2010, pp. 230-235. doi:10.1016/j.ecoleng.2008.12.036.

45. Liu F, Li J \& Zhang X: "Bioplastic production from wastewater sludge and application". Proceedings, IOP Conference Series: Earth and Environmental Science, 344, 2019, 012071.

46. Arikan E B, \& Ozsoy H D: "A Review: Investigation of Bioplastics". Journal of Civil Engineering and Architecture, V. 9, No. 2, 2015. 02/28/2015.

47. Hornbostel K \& Geiker M R: "Influence of cracking on reinforcement corrosion". Proceedings, Nordic Workshop on "Crack width calculations methods for large concrete structures”. (M Engen \& R Tan, Editors). Oslo, Norway, 2019.

48. Hager M D, van der Swaag S \& Schubert U S (Ed): "Self-healing materials". Springer International Publishing, 2016. Springer. https://doi.org/10.1007/12_2015_332. 